\title{
Türkiye'de 1960 ve 1980 Kurucu Meclisleri: Demokratik Nitelikleri Bağlamında Karşılaştırmalı Bir Değerlendirme
}

DOI: $10.26466 /$ opus.688038

\author{
Y1ldız Atmaca* -Eray Göç ** \\ * Dr. Öğr. Üyesi, Van Yüzüncü Yıl Üniversitesi, İïF, Van/Turkey \\ E-Posta: yildizatmaca@yyu.edu.tr \\ ORCID: 0000-0001-6345-4745 \\ ** Öğr. Gör. Çankırı Karatekin Üniversitesi, Yapraklı MYO,Çankırı/Türkiye \\ E-Posta: eraygoc@karatekin.edu.tr \\ ORCID: $\underline{0000-0003-3534-6645}$
}

Öz

Devletin temel organlar olarak bilinen yasama, yürütme ve yargının görev alanlarmı belirleyen, temel hak ve özgürlükleri güvence altına alarak toplumsal hayatı düzenleyen anayasalar, hukuki düzenlemelerin mimarı olarak kabul edilmektedir. Birbirinden farklı insanların bir araya gelerek oluşturduğu toplumun bekası ancak demokratik bir anayasal düzenlenmenin sağlanması ile mümkün olmaktadır. Anayasaları demokratik düzene koyan birimlerin adı ise anayasa hukukunda "kurucu meclis" olarak ifade edilmektedir. Kurucu meclis, yeni anayasa hazırlamakla görevlendirilmiş bir kuruldur. Bu kurulu, sinırlandıracak bir gü̧̈ yoktur. Anayasa üzerinde istediğgi değişikliği yapabilmektedir. Kurucu meclis, daha çok askeri darbeler sonrasında oluşturulmaktadır. Bu çalışmada, Türkiye'de uygulanan iki önemli kurucu meclisten (1960-1980) ve bu meclislerin demokratik niteliklerinden, 1961 ve 1982 Anayasalarının temel özelliklerinden de faydalanılarak karşılaştırmal olarak bahsedilmektedir. Çalışmanin temel sorunsalı ise 1960 ve 1980 kurucu meclislerinin gerçek anlamda demokratik düşünceye hizmet eden ve kurucu meclis olgusunun niteliklerini temelinde bartndıran birimler olup olmadtğ yönündeki sorulara cevap aramaktır. Çalışmada, gerekli literatür taraması yapılmış ve sonrasında içerik analizi yöntemi kullanılmıştır.

Anahtar Kelimeler: Kurucu Meclis, Demokrasi, Anayasa, Askeri Darbe, Türkiye 


\title{
Constituent Assemblies 1960 and 1980 in Turkey: A Comparative Evaluation in the Context of Democratic Qualities
}

\begin{abstract}
The constitutions, which determine the duties of the legislative, executive and judiciary, which are known as the basic organs of the state, and which secure fundamental rights and freedoms, are accepted as the architects of the legal regulations. The survival of the society, which is formed by different people, is only possible with a democratic constitutional arrangement. The names of the units that put the constitutions in a democratic order are expressed as "constituent assembly" in constitutional law. The constituent assembly is a committee tasked with preparing new constitution. There is no power to limit this board. It is able to make any change on the Constitution. The constituent assembly is formed mostly after military coups. In this study, two important constituent assembly implemented in Turkey (19601980) of the democratic nature of this Parliament and benefiting from the basic features of the 1961 and 1982 Constitutions is mentioned in comparison. The main problematic of the study is to find answers to the question of whether the constituent assemblies of 1960 and 1980 are the units that serve the real democratic thought and which are based on the qualities of the constituent assembly. In the study, the necessary literature search was made and then the content analysis method was used.
\end{abstract}

Keywords: Constituent Assembly, Democracy, Constitution, Military Coup,Turkey 


\section{Giriş}

Kurucu meclisler anayasa hukukunda, anayasa hazırlamada toplum tarafından seçilmiş kişiler olarak bahsedilmektedir. Bununla birlikte, toplumun anayasal çalışmalarının kurucu meclis eliyle yapılması gerektiği belirtilmektedir. Türkiye'de kurucu meclis eliyle hazırlanan ilk anayasal çalışma ise 1961 anayasasıdır. Bundan önce hazırlanan anayasa çalışmalarında kurucu meclisin adı, bahse dahi konu olmamıştır. İlk kez 1960 yılında yapılan çalışmalarla parlamenter düzenden kopularak 157 sayılı "Kurucu Meclis Teşkili Hakkında Kanun" ve 158 sayılı "Temsilciler Meclisi'nin Seçimi Hakkında Kanun" ile Türk anayasal düzenine kurucu meclis olgusu kazandırılmıştır. 1960'lı yılların sonlarına doğru artan siyasal şiddet olayları ve tıkanıklıklar,1961 Anayasasının değiştirilmesini zorunlu kılmıştır. Ancak anayasal değişiklik fayda etmemiş, 1970'li yılların sonlarına doğru tekrarlanan şiddet olayları karşısında askeri kuvvetler tarafından tekrar yönetime el koyulmuş ve yeni bir anayasa daha hazırlanmıştır. Hazırlandığı yıl, halk oylamasına sunularak oyların büyük bir ekseriyetini alan bu anayasa, 1982 Anayasasidır. 1982 Anayasası, darbe sonrası başa gelen ve yönetimin karar mekanizması olarak bilinen Milli Güvenlik Konseyi ve Konsey üyeleri tarafından seçilerek oluşturulan Danışma Meclisinden oluşan bir kurucu meclis eliyle hazırlanmıştır.

Anayasalar, tamamen demokratik amaç gözeterek hazırlanmaktadır. Ancak her ne kadar demokratik bir amaç güdülse dahi siyasal birlik olarak halkın gerçek anlamda temsilinin sağlanmadığı bir yönetim, demokratik yönetimden çok diktatöryal bir yönetim yapısının izlerini taşımaktadır (Cristi,1997, s.197-198). Anayasa, bir ülkedeki vatandaşların büyük bir ekseriyetinin katılımı, talep ve beklentisine duyarlılığı ölçüsünde demokratik bir niteliğe haizdir. Kurucu meclisler, Anayasa hukukunun temel çerçevesini ve bir devletin anayasa hazırlarken dikkat ettiği esas aktörü oluşturmaktadır. Bu sebeple, akademik literatürün önemli bir konusu olarak kabul edilmektedir. Ancak konuya yönelik çalışma sayısı sınırlıdır. Bu doğrultuda çalışmada, kurucu meclis olgusuna ilişkin gerekli kavramsal açklamaların ve teorik bilgilerin anlatılması sonrada 1960 ve 1980 yıllarında oluşturulan kurucu meclislerin demokratik niteliklerinin ele alınması ve karşılaştırmalı olarak değerlendirilmesi şeklinde ilerlemiştir. Çalışmada, 1960 ve 1980 kurucu meclislerinin gerçek anlamda temsil özelliğini taşıyıp taşımadığı ve 
demokratik nitelikler çerçevesinde ilgili 1961 ve 1982 Anayasalarının hazırlanıp hazırlanmadığı yönündeki sorulara cevap aranmıştır. Konu ile ilgili kapsamlı bir literatür taraması yapılmış ve elde edilen veriler analiz edilmiştir. Analiz sonucunda, Türkiye'de kurucu meclis eliyle hazırlanan her iki anayasanin da demokratik usulden, toplumsal beklentilerden ve kurucu meclis olgusunun kapsamından tamamen uzak olduğu sonucuna ulaşılmıştır.

\section{Kurucu Meclis}

Yapısal ve işlevsel anlamıyla tartışılan ve nitelikleri farklılık gösteren Kurucu Meclis olgusunun Türk siyasi ve yönetim tarihi açısından önemi büyüktür. Bu anlamda kavrama netlik kazandırmak ve demokratik nitelikleri hakkında bilgi vermek doğru olacaktır.

\section{Kavramsal Çerçeve}

Anayasayı hazırlamak üzere halk tarafından seçilerek oluşturulmuş bir meclis olma özelliğini taşıyan kurucu meclis, kökenini 1787 tarihli Amerikan Federal Anayasası'ndan almaktadır. Bu meclisler, sahip oldukları yetkiler çerçevesinde Amerikan tipi ve Fransız tipi kurucu meclisler olmak üzere iki farklı kategoride sınıflandırılmaktadır (Gençkaya, 1998, s.28). Amerikan tipi kurucu meclisin tek yetkisi anayasayı hazırlamaktır. Konvansiyon "convention" adıyla anılan bu meclisin olağan kanun yapma ve anayasayı oluşturma görevi bulunmamaktadır. Bu Meclis olağanüstü dönemlerde görev yapmaktadır. Meclisin tek görevi "kurmaktır". Kurulduktan sonra bu meclis dağılmaktadır. Amerikan tipi kurucu meclis sistemi, iktidarların sürekli aynı el altında toplanmasından doğacak sıkıntıların çıkmasına engel olması sebebiyle de beğeni toplamaktadır (Esen, 1970 s.48). Fransız tipi kurucu meclisler ise anayasa hazırlamanın yanı sıra hükümeti denetlemek ve yasa yapmak gibi olağan yasama işlemlerini de yürütmektedirler. Bu durum da asıl görevi anayasa hazırlamak olan kurucu iktidarın görevinin aksaması sonucunu doğurmaktadır (Gençkaya, 1998, s.28).

Kurucu meclisler, içerik itibari ile geçiciliği ifade etmektedirler. Anayasayı hazırlamaları ve hazırlanan anayasaların kabulü ile birlikte görevleri de sona ermektedir. Kurucu meclis fikri, milli egemenlik ilkesi ile temellendi- 
rilmektedir. Bu nedenle, meclisin demokratik niteliği doğrudan ve genel oyla seçilmesi, ülkede temel bir kamu hakkı olarak tanınmış olması ve hazırlık aşamasında geniş çaplı bir tartışma yaşanmasıyla ilişkilendirilmektedir. Genel itibari ile kurucu meclisler, temsili demokrasi ilkesine dayanmaktadır.Meclisin iradesi ulusun iradesi olarak kabul edilmekte ve alınan kararlar halkın onaylamasına sunulmamaktadır. Amerikan ve Fransız tipi anayasal düzenlemeler de bu perspektiflidir (Gözler,2000, s.86-98).

Bu bağlamda, 1960 ve 1980 yılında oluşturulan kurucu meclislerin hazırladığı anayasal çalışmalara bakıldığında, Türkiye'de uygulanan kurucu meclislerin daha çok Fransız tipi bir kurucu meclise benzerlik gösterdiği görülmektedir. 1960 kurucu meclisi çıkardığı 157 sayılı yasa ile kurucu meclisleri anayasa yapmanın yanı sıra 1961 yılında seçilerek çalışacak olan TBMM'nin seçimine kadar yasama ve yürütmeyi denetleme yetkisine muktedir kılmıştır. Aynı yasal düzenleme anayasal düzenlemeyle birlikte yeni bir seçim kanunu hazırlama yetkisini de kurucu meclislere bırakmıştır (Resmi Gazete,1960). 1980 kurucu meclisi de yine demokratik ve hukuk devletinin gerektirdiği düzenlemeleri gerçekleştirmek üzere hem 1982 anayasasını hem de seçim ve siyasi partiler kanunlarını hazırlamakla görevlendirilmiştir. Yalnız, Türkiye'deki kurucu meclisler, Amerikan ve Fransız tipi kurucu meclislerden farklı olarak hazırlanan anayasal düzenlemeleri halkoyuna sunmaktadır.

\section{Kurucu Meclisin Demokratik Niteliği}

Anayasalarda olması gereken temel niteliklerin en önemlisi, demokratik meşruluk özelliği ve anayasaların hazırlanması sırasında bütün toplumsal kesimin temsil edilmesidir. Toplumsal bütünlüğün sürece katılımı ve her kesimin bu süreçte yer alması ilgili anayasanın demokratik meşruluğunu arttırmaktadır. Anayasa, bir ülkedeki vatandaşların temel hak ve özgürlüklerini düzenleyen, siyasi iktidarın örgütlenmesini ve iktidara karşı özgürlükleri belli güvencelerle ele alan toplumun genelini ilgilendiren ve geleceklerini belirleyen önemli bir kurucu belgedir. Bu sebeple, böyle bir kurucu belgenin hazırlanması sırasında sürece toplumun hemen hemen bütün kesimlerinin katılması ve temsil edilmesi gerekmektedir (Dursun, 2001).

Kurucu meclisler, anayasa hazırlamalarında demokratik niteliği arttıracak, toplumun büyük bir kesimini temsil edecek önemli bir mekanizma 
olarak kabul edilmektedir. Anayasa hukukunda kurucu meclis, "anayasa yapmak üzere toplum tarafından seçilen özel bir meclis" olarak tanımlanmaktadır. Buradaki, "toplum tarafından seçilmiş olmak" ve "anayasa yapmak amaciyla seçilmiş olmak" cümlelerine dikkat etmek gerekmektedir. Cümle, toplumun seçmediği ve anayasa yapmak üzere seçilmiş olmayan bir meclisin, kurucu meclis olarak kabul edilmeyeceğini ifade etmektedir (Teziç, 2005, s.207-208).

Temelinde temsili demokratik sistemin düşüncelerini barındıran kurucu meclislerin doğasında "milli egemenlik" teorisi yer almaktadır. Bu teoride, egemenlik yalnızca millete aittir. Bu doğrultuda, vatandaşın egemenlik hakkını doğrudan kendisi kullanamamaktadır. Zira millet, bireyden ayrı bir hukuki kişiliğe sahiptir. Millet adında sadece irade beyanında bulunabilecek temsilcilere ihtiyaç duyulmaktadır. Kurucu meclisler, anayasa hazırlama sürecinde bu temsilcilerin bir araya gelmesi sonucu ortaya çıkan bir teşekkül olarak kabul edilmektedir. Milli egemenlik teorisinde anayasalar bir sözleşme değil daha çok milletin tek taraftan oluşan bir irade beyanıdır. $\mathrm{Bu}$ sebeple, milli egemenlik teorisi çerçevesinde anayasalar kurucu meclisler tarafından hazırlanmakta ve "kanun tipi anayasa" olarak da anılmaktadır (Şahin, 2017, s.552).

Anayasanın demokratik meşruiyetini sağlamak amacıyla oluşturulan özel kurullar olarak kabul edilen kurucu meclisler, toplumun bütün kesimlerini temsil eden bir kurucu iktidar yetkisine sahiptirler. Ancak kurucu meclis eliyle hazırlanan her anayasa, demokratik meşruiyeti sağlama noktasında yeterli özelliğe sahip değildir. Anayasaların kurucu meclisler tarafından hazırlanması doğal bir şarttır. Ancak yeterli değildir. Kurucu meclisler tarafından hazırlanan anayasaların içeriğinin de demokratik ilkelere, standartlara ve kurumlara sahip olması gerekmektedir. Modern demokrasinin gelişmişliklerini dikkate almayan, temel hak ve özgürlükleri kapsamlı bir şekilde düzenlemeyen, iktidarı sınırlamayan, siyasi iktidara karşı bu hak ve özgürlükleri garanti altına almayan bir anayasal düzenlemenin demokratik meşruluğa sahip olduğunu söylemek doğru olmayacaktır (Dursun,2001). Anayasa hazırlamanın demokratik meşruiyeti, farklı kimliklerin uzlaşmasını sağlayan kapsayıcı ve katılımcı bir yapıyla mümkün olabilecektir. Bu yapı, savunmasız grupları ve azınlıkları koruyan tüm bireylerin altında yer aldığı bir şemsiye görevini görmektedir. Kişilerin farklı düşünce yapılarına sahip olduğu ancak bir araya gelebildiği, korkmadan özgürce tartışabildiği 
bir platform rolünü üstlenen meclisler ile anayasaların demokratik meşruiyeti daha da etkinleşecektir (Gülener,2011, s.62-65).

\section{Anayasası ve Kurucu Meclisi}

1961 Anayasası bir darbe anayasasıdır. Bu darbe, 27 Mayıs 1960 tarihinde Tanzimat'tan bugüne modernleşme ve yenileşme hareketlerine öncülük eden askeri ve sivil bürokrasi ile aydın kesimin, çok partili hayata geçilmesi sonrasındaki çalışmalarda ikinci plana atılmalarına karşılık gösterilen bir tepkidir. 1960 darbesinin, daha çok demokratik niteliklerini kaybetmek üzere olan bir iktidara yeniden demokratik niteliklerini kazandırmak amaciyla yapıldığı belirtilmektedir (Tunç ve Bilir, 2005, s.10).

Çağdaş Türkiye'de anayasa yapılmasında parlamenter düşünce sisteminden ilk ayrılma 1960 yılında olmuştur. 13 Aralık 1960 tarihli ve157 sayılı "Kurucu Meclis Teşkilatı Hakkında Kanun" ile 158 sayılı "Temsilciler Meclisi'nin Seçimi Hakkında Kanun" Türk anayasa sistemine kurucu meclis kurumunu getirerek,kurucu meclisi "korporatif" yapıya dayandırmıştır (Parla,1984:218). Kurucu meclis, Milli Birlik Komitesi'nden ve "mevcut şartlara uygun olarak milletin en geniş manasiyla temsili gayesini gözeten" Temsilciler Meclisi'nden oluşmaktadır. 157 sayılı kanun iki farklı meclisten oluşan kurucu meclisin başlıca görevini ise yeni bir anayasayı görüşüp karara bağlamak ve yeni bir seçim kanunu hazırlamak olarak belirtmiştir (Resmi Gazete,1960).

Milli Birlik Komitesi (MBK), TBMM'nin yetkilerine sahiptir. Yasama yetkisini bizzat kendisi, yürütme yetkisini ise kendi seçtiği bakanlar eliyle kullanmaktadır. Devlet başkanlığı makamı olan cumhurbaşkanlığı, başbakan, başkomutan ve MBK başkanlığ1 yetkilerini kendi tekelinde birleştirmiştir (Tunç ve Bilir, 2005, s.10). Temsilciler meclisi ise devlet başkanı ve MBK tarafından atanacak olan temsilciler, il temsilcileri, bakanlar kurulu üyeleri, siyasi parti temsilcileri ve meslek kuruluşlanı temsilcilerinden oluşmaktadır(Resmi Gazete:1960). Temsilciler Meclisi, kurucu mecliste daha çok bir danışma birimi olarak, MBK ise karar mekanizması olarak işlev görmektedir.

MBK, başa geldiği ilk günde ve sonrasında sadece ülkenin ihtiyaçlarını karşılayacak bir anayasal çalışmanın hazırlanması gerektiği düşüncesini benimsemiştir. Bu sebeple de öğretim üyelerinden oluşturulan bir komisyo- 
nu anayasa hazırlamakla görevlendirmiştir. Bu komisyon, İstanbul Üniversitesi Hukuk Fakültesi öğretim üyelerinden oluşmaktadır. Öğretim üyelerince hazırlanan anayasa taslağ 1 ise "İstanbul Tasarısı" olarak kabul edilmektedir. 191 maddeden oluşan bu tasarı, siyasi partilere ve genel oya güvensizlik üzerine kurgulanmıştır. Siyasi partilerin etkisiz hale getirilmesi istenmiştir. Tasarı, iktidarı çeşitli organlar arasında bölen Devlet Şurası, Milli Savunma Şurası, Türkiye Milli Bankası, Üniversiteler, TRT, Milli Kütüphane gibi özerk kurul veya kuruluşlar ortaya çıkarmıştır. İstanbul Tasarısı, yürütmenin zayıflatılmasını istemiş, ikinci bir korporatif meclisin olması gerektiğini dile getirmiştir. Ancak İstanbul tasarısı daha çalışmalarını sonlandırmadan Ankara Üniversitesi Siyasal Bilgiler Fakültesi İdari Bilimler Enstitüsü tarafından "Gerekçeli Anayasa Tasarısı ve Seçim Sistemi Hakkındaki Görüş" adında bir tasarı yayınlanmıştır. Kısaca, Ankara Tasarısı olarak kabul edilen bu tasarı, İstanbul Tasarısından farklı olarak siyasi partileri ve genel oyu benimsemiş, yürütme biriminin zayıflatılmaması gerektiğini özellikle belirtmiştir. Bu doğrultuda, 1960 yılında kurulan kurucu meclis, 1961 yılında toplanarak ilk anayasal çalışmalarına başlamak üzere bir anayasa komisyonu oluşturmuştur. Komisyon, etüt metni olarak İstanbul Tasarısını, yardımcı metin olarak da Ankara Tasarısını esas almıştır. Tasarı çalışmalarının sonucu, Temsilciler Meclisine sunulmuştur ve Tasarının, İstanbul tasarısından ziyade Ankara Tasarısına yakın olduğu anlaşılmıştır. En son MBK'de de ayrıca görüşülen Anayasa Tasarısı, 9 Temmuz 1961 tarihinde halk oylamasına sunularak halkın yüzde 61,7 'sinin oyunu alarak kabul edilmiştir (Gözler, 2000, s.77-90).

\section{Anayasası ve Kurucu Meclisi}

1960'lı yılların sonlarına doğru Türkiye'de bir takım siyasal şiddet olayları artmıştır. Bu olayların önüne geçilemeyince 12 Mart 1971 tarihinde ve Genelkurmay Başkanı ile birlikte Kuvvet Komutanları tarafından hükümete bir "muhtıra" verilerek dönemin başbakanı Demirel istifaya zorlanmıştır. İstifa eden Demirel'in ardından ordunun desteğiyle birlikte "partiler üstü" bir hükümet kurulmuş ve Anayasada değişiklikler yapılması gerektiği düşüncesi gündeme oturmuştur (Yazıcı, 1997, s.101-134).Yapılan bazı anayasal değişikliklere rağmen 1975 'den sonra siyasal şiddet olayları tekrar devam etmiştir. Siyasal sistemde ciddi tıkanıklıklar yaşanmıştır. 6 ay boyunca 
TBMM Cumhurbaşkanını seçememiştir. Meclis kanun çıkartamamış hükümetler ise karar alamaz olmuştur. Yürütmenin zayıflatılması ve devlet otoritesinin azaltılması ilkesini benimseyen 1961 Anayasası, bütün bu krizlere gerekçe olarak gösterilmiştir. Bu sebeple, 1980 yılında 1961 Anayasasının tamamen değiştirilmesi gerektiği düşüncesi tartışılmaya başlamıştır (Özbudun, 2003, s.24-25).

Siyasi iktidarsızlık ve ekonomik problemlerin devam etmesine bağlı olarak, 1980 yılında Türk Silahlı Kuvvetleri tarafından emir komuta birliği yapısı içerisinde bir darbe yapılmıştır. 1982 Anayasası, 12 Eylül 1980 tarihinde askeri darbeyi yapanlar tarafından hazırlanmıştır. Askeri darbe iktidarı, darbenin altında yatan temel faktörün bir tarihi sorumluluk duygusu olduğunu belirtmiştir. Kendisine Milli Güvenlik Konseyi (MGK) adını yakıştıran askeri iktidar, önce 1980 yılında bir kurucu meclis oluşturmuştur (Tanör, 1994, s.97-176). MGK üyeleri, "milletin kayıtsız şartsız egemenliğine, demokratik ve laik cumhuriyet ilkelerine dayalı yeni bir anayasa düzeni" kurulacağı düşüncesini tekrarlamış ve hazırladıkları 1982 Anayasasını referanduma sunmuştur. Böylelikle, halkoylamasının yüzde 91,37'sinin "evet" oyunu alan 1982 Anayasası, kabul edilmiştir(Tunç ve Bilir, 2005, s.13).

1980 kurucu meclisi, iki kanattan oluşmuştur. Birinci kanadı, darbe erkinin kendisinden oluşan MGK, ikinci kanadı ise doğrudan veya dolaylı olarak MGK tarafından seçilen üyelerin yer aldığı Danışma Meclisi'dir. Danışma Meclisi'nin yapısı toplumun tamamın temsil edecek nitelikte değildir. Üyelerinin büyük bir çoğunluğu bürokrat kökenlidir. 12 Eylül 1980 yılı öncesinde herhangi bir siyasi partiye üye olanların Danışma Meclisi'ne üye olması mümkün değildi. Kurucu meclis içerisinde, MGK'nın yetkisi Danışma Meclisi'ne göre daha fazladır. MGK, kurucu meclisin almış olduğu kararların en son onay merciidir. Gerekli görüldüğü zaman yasama yetkisini, Danışma Meclisi'nin görüşünü almadan da alabilmektedir. Danışma Meclisi ise en az on üyenin imzasını alarak yasa teklifinde bulunabilmektedir. Bakanlar kurulu, sadece MGK'ya karşı sorumludur (2018, s.1-4).

\section{0 ve 1980 Kurucu Meclislerinin Demokratik Niteliği}

Gerek 1961 Anayasası gerekse 1982 Anayasası, hazırlandığı dönemin izlerini taşıyan önemli anayasal düzenlemelerdir. Bu yıllarda siyasal, ekonomik ve sosyal sorunlar yönetimde iyileştirmelerin yapılmasını gerektirmiştir. 
1960 ve 1980 kurucu meclisleri ise Türk tarihinde bu iyileştirmelerin hukuksal boyutunu ele alan köklü bir anayasal değişiklik durumunu gündeme getirerek anayasal çalışmaları yapan iki önemli meclis olarak kabul edilmektedir.

1961 ve 1982 Anayasaları, askeri darbeler sonrasında oluşturulmuştur. Darbe sonrası bir kanadında askerlerin (MBK ve MGK) diğer kanadında ise sivillerin (Temsilciler Meclisi ve Danışma Meclisi) yer aldığı Kurucu Meclis, yeni anayasanın oluşturulmasında esas aktör olarak yer almıştır. Hem 1961 Anayasası'nı hem de 1982 Anayasası'nı hazırlamak üzere oluşturulan Kurucu Meclislerin asker, sivil hiç bir üyesi seçimle belirlenmemiştir. Bunun yanı sıra sivil üyelerin yer aldığı Temsilciler Meclisi ve Danışma Meclisi'ne Bakanlar Kurulu'nun kurulması ve düşürülmesine ilişkin herhangi bir yetki verilmemiştir (Tunç ve Bilir, 2005, s.16).

1960 Kurucu Meclisi'nde hâkim olan ideolojik düşünce, CHP kökenli aydınlara aittir. Bu durum, muhafazakâr tabanlı kesimde memnuniyetsizlik doğurmuş ve uyuşmazlıkların ortaya çıkması durumunu doğurmuştur. Seçimden çok atama ile oluşturulan 1960 kurucu meclisinde Temsilciler Meclisi, seçimlerden ziyade tabii bir üyeliği ifade etmekte, tercihli bir partiyi ve korporatif yapıyı göstermektedir. Daha da özelde, "milletin en geniş manasıyla temsili gayesini gözeten" bir yapıyı değil, iktidarın belirlediği korporatif ve korporatif olmadığı düzeyde dar bir territoryal sistemi temsil etmektedir. Kurucu meclisin karar mekanizması olarak kabul edilen MBK'nin de yine temsil ile uzaktan yakından bir alakası yoktur. Tamamen darbe iktidarının aldığı kararlar yönünde hareket edilmektedir (Parla,1984, s.219). Bu sebeple, 1961 Anayasası, "serbest seçimden faydalanamayan ve büyük ölçüde otoriter rejimin kontrolü altında bulunan, temsili niteliğe sahip olmayan bir heyet veya meclis tarafindan yapılması yolunun tipik bir örneği" olarak kabul edilmektedir (Özbudun,1993, s.58). Özbudun (2003, s.23),1961 yılında halk oylamasıyla kabul edilen 1961 Anayasası'nın, Türk toplumunun bazı kesimlerinde muhalefetle karşılandığını iddia etmektedir.1961 yllinda toplumun \%61'nin evet oyunu alarak bir anayasa oluşturulduğunu ancak seçimlerin tam bir serbestlik içerisinde gerçekleştirilmediğini, Demokrat Parti eski seçmenlerinin tam örgütlenmemiş olmasına rağmen Anayasaya karşı \%40'a yakın bir hayır oyunun çıkmasını göz önünde bulundurmak gerektiğini dile getirmektedir. Bu durum da 1961 Anayasas1nın toplumun büyük bir çoğunluğunu temsil eden bir toplum sözleşmesi 
olduğu yönündeki düşüncelerin şüpheyle karşılanması sonucunu doğurmuştur. Ancak genel anlamda 1961 Anayasası, kendinden önce uygulanan anayasaların aksine kuvvetlerin yumuşaklığı ilkesini benimsemiş, yerel yönetimlerdeki karar organlarının seçimle başa gelmesini düzenlemiş ve demokratik bir hayat için siyasi partileri olmazsa olmaz güç olarak göstermiştir (Gözler, 2000, s.80-92). Anayasa başlangıç kısmında yer alan, "İnsan hak ve hürriyetlerini, milli dayanışmayı, sosyal adaleti, ferdin ve toplumun huzur ve refahını gerçekleştirmeyi ve teminat altına almayı mümkün kılacak demokratik hukuk devletini bütün hukuki ve sosyal temelleriyle kurmak için; Türkiye Cumhuriyeti Kurucu Meclisi tarafından hazırlanan...." ibaresi ile de demokratik ve sosyal bir hukuk devlet modelli amaç güttüklerini yasal çerçeveyle desteklemiştir (Resmi Gazete,1961).

1982 Anayasası'nın hazırlanmasına ilişkin süreçteki mimar ise toplum değildir. Tarihi bir sorumluluk duygusu doğrultusunda hareket edildiğinin altını çizen ve anayasadaki son düzenlemeleri yapan askeri darbe iktidarının temsilcisi, MGK'dir. Bu sebeple 1982 Anayasasını, bir toplum anayasası olarak kabul etmekten çok MGK anayasası olarak kabul etmek daha doğru olacaktır (Tanör,1994, s.97).

1982 Anayasası, 1980 askeri darbesi sonrasında Kurucu Meclis tarafından hazırlanan ve ayn yıl yapılan halk oylamasında yüzde 91,37 oranında "evet" oyu alarak kabul edilen önemli bir anayasal düzenlemedir. Darbenin neden yapıldığına ilişkin olarak yayımlanan MGK bildirisinde, "Girişilen harekâtın amac1, ülke bütünlügünü korumak, millî birlik ve beraberliği sağlamak, muhtemel bir iç savaşı ve kardeş kavgasını önlemek, devletin otoritesini ve varlığını yeniden tesis etmek ve demokratik düzenin işlemesine mani olan sebepleri ortadan kaldırmaktır." şeklinde ortaya konmuştur. Bu açıklamadan da anlaşılacağı üzere, Kurucu Meclisin karar mekanizması olan MGK'nın anayasa hazırlamasındaki temel güdüleyicisi, özgürlüklerin veya demokrasinin geliştirilmesi değil, otoritenin ve devletin güçlendirilmesi, güvenliğin tesisidir.1982 Anayasasın 1961 Anayasasından daha az demokratik kılan sebeplerden biri de budur. 1960 Kurucu Meclisi, 1980 Kurucu Meclisi'ne göre devleti ve otoriteyi daha da güçsüzleştirmiştir. Bu durum 1982 Anayasasın, özgürlüklere daha az yer veren ve devlet otoritesini artt1ran bir anayasa özelliğini kazandırmıştır.1982 Anayasası, daha az katılımcı ve çoğulcu olmayan bir yapıyı benimsemiştir. Anayasa, 1980 darbesini yürütmenin zayıflatılması ve devletin etkisizleştirilmesiyle bağdaştırması se- 
bebiyle 1961 Anayasasına karşın genelde yürütmeyi, özelde ise cumhurbaşkanını güçlendirmiştir (Çekiç, 2016, s.456-457).

1961 yılında yapılan halkoylamasında siyasal partilerin kamuoyu içerisindeki katılımı aktif kılınmıştır. Bu dönemde anayasanın kabulüne karşı olan düşünceler belli sınırlar dâhilinde rahatlıkla ifade edilebilmiştir. Ancak 1982 yılında yapılan halk oylamasında siyasi partilerin kamuoyu karşısındaki katılımları aktif kılınmadığı gibi görüş bildirmeleri bile yasaklanmıştır (Tunç ve Bilir, 2005, s.17). Bu durum, “Siyasi partilerin tüzük ve programları ile eylemleri, Devletin bağımsızlığına, ülkesi ve milletiyle bölünmez bütünlüğüne, insan haklarına, eşitlik ve hukuk devleti ilkelerine, millet egemenliğine, demokratik ve laik Cumhuriyet ilkelerine aykırı olamaz; sınıf veya zümre diktatörlüğünü veya herhangi bir tür diktatörlüğü savunmayı ve yerleştirmeyi amaçlayamaz; suç işlenmesini teşvik edemez" ve "Bir siyasi partinin tüzügü ve programının 68 inci maddenin dördüncü fikrası hükümlerine aykırı bulunması halinde temelli kapatma kararı verilir" şeklinde Anayasanın 68. ve 69. maddelerinde belirtilmiştir.

\section{Sonuç ve Değerlendirme}

Türk Anayasa hukuku tarihinde, kurucu meclis eliyle hazırlanan sadece iki anayasa bulunmaktadır. Bu anayasalar da 1961 ve 1982 anayasalarıdır. Ancak ilgili anayasaları hazırlayan kurucu meclislere, içerik itibari ile bakıldığında bir kurucu meclis niteliğini taşımadığı ve demokratik niteliklerinin olmadığı anlaşılmaktadır. Kurucu meclis, en yalın hali ile anayasa hazırlamak üzere toplum tarafından seçilen insanlar olarak tanımlanmaktadır. 1960 ve 1980 Kurucu Meclisleri vatandaşın seçtiği kişilerden oluşturulmamış, tam tersine seçimle işbaşına gelmiş siyasi iktidara karşı, bu iktidarların demokratik niteliklerden uzaklaştıkları iddiasıyla darbe gerçekleştirmiş olan askerler tarafından belirlenmiş kişilerden oluşturulmuştur. Bu meclislerin karar mekanizması ise yine darbe ile başa gelen askeri kuvvetlerin temsilcilerinden (MBK ve MGK) oluşmaktadır. Mecliste ayrıca ikinci kanat olarak kabul edilen Temsilciler Meclisi ve Danışma Meclisi de bulunmaktadır. Bu meclisler, yapısal ve işlevsel yönleri gereği toplum tarafından seçilen kişilerden oluşmaktadır. Ancak her iki mecliste kurucu meclisin karar makamı olan MBK ve MGK üyeleri tarafından seçilmektedir. Bu durum da oluşturu- 
lan istişare amaçlı meclislerin demokratik yapıdan ne derece uzak olduğunun somutlaşmış görünümü olarak ortaya çıkmaktadır.

1961 ve 1982 Anayasaları, darbe sonrası halkın psikolojik olarak yıkıldığı bir zamanda ve demokratik olmayan yapılanmaların olduğu bir ortamda kabul edilmiştir. Konu üzerine araştırmalar yapan birçok bilim insanı, böyle bir ortamda kabul edilen anayasaların hiçbir şekilde demokratik olmadığ kanaatini paylaşmaktadır. Nitekim MBK ve MGK tarafından hazırlanan anayasaların hazırlanışı esnasında da hiçbir şekilde toplumun fikri alınmamış, talep ve beklentileri sorulmamıştır. Bu doğrultuda, her ne kadar demokratik nitelikleri arttırma doğrusuyla hareket edildiği iddia edilse de 1961 ve 1982 Kurucu Meclislerini demokratik saymak mümkün değildir.

1961 Anayasası, toplumun \%61'i tarafından kabul edilmiştir. O zamanki koşullarda gerçekleştirilen bir seçim perspektifiyle bakıldığında geriye kalan \%40'llk kesimin temsil gücünün ne olduğunu veya ne düşündüğünü sorgulamak gerekmektedir. Zira \%40’llk bu kesim, çoğulcu demokratik yönetim anlayışının, toplumsal yaşamdaki her türlü düşüncenin ülke yönetiminde söz sahibi olmasını ön gören eşitlikçi ve özgürlükçü düşünce yap1slyla uyumluluk göstermemektedir (Dow,2004, s.283-285).

Son tahlilde, ilk anayasa olarak kabul edilen 1876 Anayasası'ndan bu yana beş farklı anayasanın yürürlüğe girdiği Türkiye'de, demokratik perspektifte gerçekleştirilen bir anayasal çalışmanın söz konusu olmadığını söylemek mümkündür. Zira bugün hala Türkiye'de demokratik olmadığı gerekçesiyle yeni bir anayasanın hazırlanması gerektiği savını dile getiren eleştiriler mevcuttur. Bu durum da Türkiye'nin bir anayasa sorunu olduğu gerçeğini ortaya koymaktadır. Gerçek bir kurucu meclisin toplumun bütün kesimini temsil edecek ve hiçbir sınırlamaya tabi tutmayacak bir yapıya sahip olması gerekmektedir. Türkiye, sağlıklı ve demokratik bir yapıyla yapılandırılmış bir anayasa hazırlayabilmek için bu kapsamda bir kurucu meclis oluşturmalıdır. Böyle bir Meclis, temsil sisteminin gücünü arttıracak ve demokratikleşme yolunda Türkiye'ye büyük kazanımlar sağlayacaktır (Dursun,2001). Bu sebeple yola, toplumun bütün ekseriyetini kapsayacak, demokratik bir kurucu meclis oluşturmakla başlamak gerekmektedir. 


\section{EXTENDED ABSTRACT}

\section{Constituent Assemblies 1960 and 1980 in Turkey: A Comparative Evaluation in the Context of Democratic Qualities \\ * \\ Yıldız Atmaca - Eray Göç \\ Van Yüzüncü Yal University, Çankır Karatekin University}

Constitutions are prepared with a completely democratic purpose. However, even though a democratic goal is pursued, a government in which the people are not really represented as a political union carries the traces of a dictatorial government rather than a democratic government. A Constitution has a democratic character in the extent of the participation of a large majority of citizens in a country, its sensitivity to demand and expectation.

The constituent assemblies express temporality in terms of content. Their duties end with the preparation of the constitution and the acceptance of the prepared constitutions. The idea of the constituent assembly is based on the principle of national sovereignty. Therefore, the democratic quality of the parliament is directly and generally voted, associated with the fact that it is recognized as a basic public right in the country, and that there is a wideranging debate in the preparatory phase. In general, the constituent assemblies are based on the principle of representative democracy. For this reason, the will of the council is accepted as the will of the nation and the decisions taken are not submitted to the approval of the public. American and French type constitutional regulations are also from this perspective.

Constituent assemblies are considered as an important mechanism that will increase democratic quality and represent a large part of the society in their constitution drafting. In constitutional law, the constituent assembly is defined as "a special assembly elected by the society to make a constitution". The terms "being chosen by the society" and "being chosen to make a constitution" are remarkable. In short, a assembly that is not chosen by the society and is not elected to constitute is not accepted as a constituent assembly. 
The theory of "national sovereignty" is inherent in the constituent assemblies that basically contain the ideas of the representative democratic system. In this theory, sovereignty belongs only to the nation. Accordingly, the citizen cannot directly exercise its right to sovereignty. Because the nation has a separate legal personality from the individual. Only representatives who can make declaration of will in the name of the nation are needed. Constituent councils are considered as an organization that emerges as a result of these representatives coming together during the constitution preparation process. In the theory of national sovereignty, constitutions are not a contract, but rather a declaration of will from the nation. For this reason, constitutions are prepared by the constituent assemblies within the framework of the national sovereignty theory and are also referred to as "law type constitution".

Constituent assemblies, which are accepted as special boards formed to ensure the democratic legitimacy of the Constitution, have a founding power of authority representing all segments of the society. However, every constitution prepared by the constituent assembly does not have sufficient features to ensure democratic legitimacy. It is a natural requirement that constitutions are prepared by the constituent assemblies. However, it is not enough. The content of the constitutions prepared by the constituent assemblies must also have democratic principles, standards and institutions. It would not be correct to say that a constitutional regulation that does not take into account the developments of modern democracy, does not regulate fundamental rights and freedoms comprehensively, does not limit power, does not guarantee these rights and freedoms against political power, has democratic legitimacy.

The constituent assemblies form the basic framework of the Constitutional law and the main actor a state pays attention to when preparing the Constitution. For this reason, it is accepted as an important subject of academic literature. However, the number of studies on the subject is limited. In this regard, the study proceeded as the necessary conceptual explanations and theoretical information about the phenomenon of the constituent assembly, and then the democratic qualities of the constituent assemblies formed in 1960 and 1980 were evaluated and compared. In the study, answers were sought for the questions whether the constituent councils of 1960 and 1980 were truly representative and whether the relevant 1961 and 
1982 Constitutions were prepared within the framework of democratic qualifications. A comprehensive literature review was made on the subject and the data obtained were analyzed. Analysis showed that both the constitution prepared by a constituent assembly in Turkey in the democratic process as hand, it was understood that the remote is fully covered by the social expectations of the patients and the constituent assembly. It was concluded that the founding councils of the 1960s and 1980s were not made up of the people elected by the citizens, but on the contrary, they were made up of people determined by the soldiers who had taken the coup against the political power that came to power with the election.

\section{Kaynakça / References}

Başbakanlık (1960). Resmi Gazete, No:10682.

Cristi, R. (1997). Carl Schmitt on sovereignty and constituent power. Canadian Journal Of Law \& Jurisprudence, 10(1), 189-201.

Çekiç, M. (2016). 1982 Anayasası'nın hükümet sistemi açısından değerlendirilmesi. Uyuşmazlk Mahkemesi Dergisi, 7, 441-478

Dow, Sheila. C. (2004). Structured pluralism. Journal of Economic Methodology, 11(3), ,275-290.

Dursun, D. (2001). Anayasa değişikliği değil, Yeni Bir Anayasa. Yeni Şafak

Esen, B. N. (1970), Anayasa hukuku genel esaslar. Ankara:Ayyıldız

Gençkaya, Ö. F. (1998). Türk Siyasal Sisteminde Kurucu Meclis. Ed. Suna Kili 27 Mayıs 1960 Deorimi, Kurucu Meclis ve 1961 Anayasası, içinde İstanbul:Boyut Yayıncilık,

Gözler, K. (2000). Türk Anayasa Hukuku. Bursa:Ekin Kitabevi.

Gülener, S. (2011). Karşlaştırmalı bir perspektiften anayasalar ve temsil ettikleri değerler. Liberal Düşünce, 16, 61-75

Özbudun, E. (1993). Demokrasiye geçiş sürecinde anayasa yapımı.Ankara.

Özbudun, E. (2003). Türk Anayasa Hukuku. Ankara:Yetkin Yayınları.

Parla, T. (1984). Anayasalar ve kurucu meclisler üzerine bazı karşlaştırmalı notlar. İktisat Fakültesi Mecmuası, 38(3-4), 207-221

Şahin, A. (2017). Kurucu meclis kavramı ve Türkiye. 1st International Congress on Vocational and Technical Sciences, Nisan 8-12, Batumi- Georgia.

T. C. 1961 Anayasası (1961). Resmi Gazete, Sayı:10816.

T.C Cumhurbaşkanlığ (t.y). Mevzuat bilgi sistemi. www.mevzuat.gov.tr adresinden erişilmiş̧ir.

Tanör, B.(1994). İki Anayasa:1961 ve 1982. İstanbul:Beta Yayınları. 
Teziç, E. (2005), Anayasa Hukuku, Beta Yayınlanı, İstanbul

Tunç, H., ve Bilir, F.,(2005), Anayasa Hukuku uygulamaları. Ankara:Nobel Yayın,

Yardımcı Kaynaklar (t.y). 1982 Anayasası için kurucu meclis nasıl oluştu? Özellikleri nelerdir? 23.04.2018 tarihinde http://www.yardimcikaynaklar.com/1982anayasasi-kurucu-medis/ adresinden erişilmiştir.

Yazıc1, S. (1997), Türkiye'de askeri müdahalelerin anayasal etkileri, Ankara:Yetkin Yayınları.

\section{Kaynakça Bilgisi / Citation Information}

Atmaca, Y. ve Göç, E. (2020). Türkiye'de 1960 ve 1980 kurucu meclisleri: Demokratik Nitelikleri bağlamında karşılaştırmalı bir değerlendirme. OPUS-Uluslararası Toplum Araştırmaları Dergisi, 16(28), 1524-1540. DOI: 10.26466/opus.688038 